UNIVERSIDADE DE SÃO PAULO

ESCOLA DE EDUCAÇÃO FÍSICA E ESPORTE

COMPLEXIDADE, ORGANIZAÇÃO E EXERCícIO FÍSICO

Antonio Pakenas

SÃO PAULO

2009 


\title{
COMPLEXIDADE, ORGANIZAÇÃO E EXERCíCIO FÍSICO
}

\author{
ANTONIO PAKENAS
}

Projeto de Mestrado apresentado à Escola de Educação Física e Esporte, como requisito parcial para obtenção do grau de Mestre em educação Física.

ORIENTADOR: PROF. DR. BENEDITO PEREIRA 
Pakenas, Antonio

Complexidade, organização e exercício físico / Antonio

Pakenas. - São Paulo: [s. n.], 2008.

$$
\text { iv, 59p. }
$$

Dissertação (Mestrado) - Escola de Educação Física e Esporte da Universidade de São Paulo.

Orientador: Prof. Dr. Benedito Pereira.

1. Complexidade $\quad$ 2. Organização $\quad 3$. Exercício Físico I. Título.

\section{SUMÁRIO}

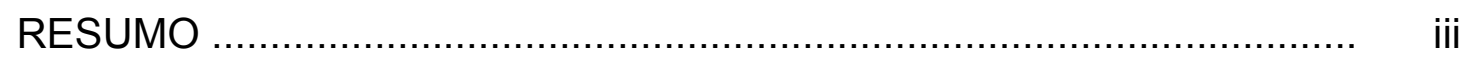

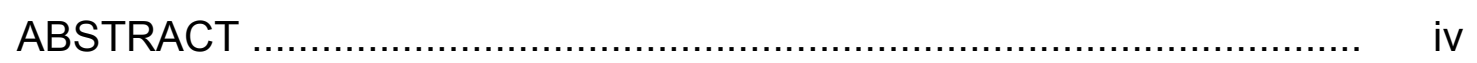

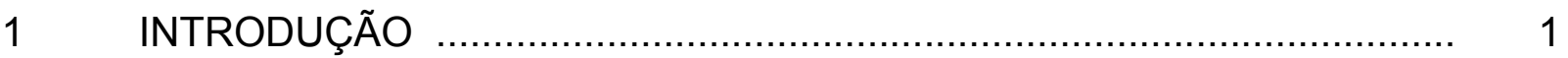

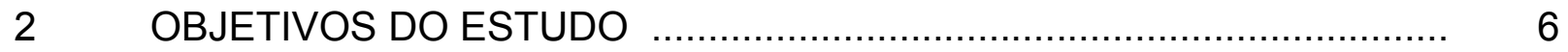

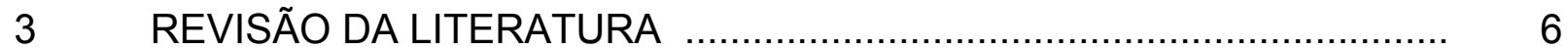

3.1 A direção do desenvolvimento: há uma seta do tempo para a biologia? . 6

3.2 A estrutura temporal dos seres vivos ................................................ 32

3.3 Modelo de assimetria temporal para o músculo e células satélites ........ 41

$4 \quad$ DISCUSSÃO ............................................................................ 42

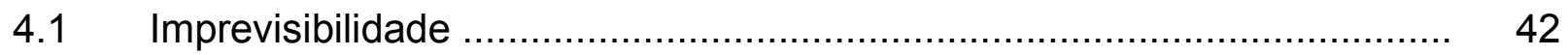

4.2 Transformação da complexidade em simplicidade ................................ 46 


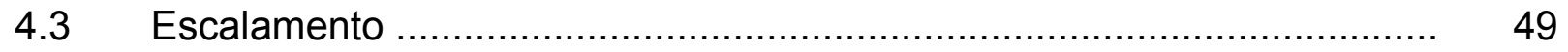

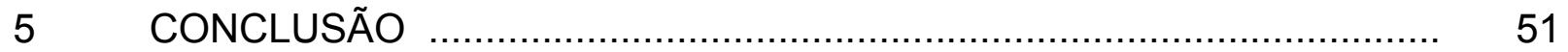

REFERÊNCIAS BIBLIOGRÁFICAS .................................................. 52

\title{
RESUMO
}

COMPLEXIDADE, ORGANIZAÇÃO E EXERCÍCIO

\author{
Autor: Antonio Pakenas \\ Orientador: Benedito Pereira
}

\begin{abstract}
A literatura especializada tem estudado a célula muscular extensivamente. De fato, existem muitos dados descrevendo alterações na concentração de substâncias, atividade enzimática e síntese (ou degradação) de moléculas durante e após o exercício físico. Entretanto, o uso de referenciais teóricos, que torna essas informações significativas, é parco. O pesquisador, por sua vez, não consegue fazer previsões de fenômenos relacionados ao exercício físico acima do nível óbvio. Para tanto, ele deve encontrar meios de análise que possibilitem a interação entre as partes analisadas e aquelas encontradas em níveis de análise mais abrangentes. No caso do músculo esquelético, células satélites podem ser o nível preferencial de escolha, já que constituem o único meio de perpetuação desse tecido. As células satélites são, portanto, o agente que concretizará a atividade muscular e a relação com outros tecidos que compõem o ser vivo. Assim, torna-se importante saber como o exercício
\end{abstract}


físico pode influenciar o comportamento das diferentes populações de células satélites, algo possível mediante o emprego de modelos teóricos. Portanto, o presente trabalho tem por objetivo caracterizar o papel das teorias relacionadas à complexidade e organização.

Palavras-chave: complexidade, organização, exercício físico

\section{ABSTRACT \\ COMPLEXITY, ORGANIZATION AND EXERCISE}

Author: Antonio Pakenas

Adviser: Benedito Pereira

The especialized literature has studied muscle cell extensively. In fact, there are most data describing alterations in the concentration of substances, enzymatic activity, and synthesis (or degradation) of molecules during and after the physical exercise. However, it is scant the utilization of theoretical frameworks that turn these informations into relevant information. The researcher, in turn, do not obtain forecasts of phenomena related to physical exercise above a obvious level. In this way, he must look for means of analysis that enable the interactions among analysed parts and those found in levels os analysis more abrangent. In the case of muscle cell, satellite cells can be the preferential level of choice, since constitute the one mean of perpetuation of this tissue. The satellite cells are, therefore, the agent that will concretize the muscular activity and the relatioship with other tissues which compose the being. Thus, it is important to know as physical exercise can influentiate the behaviour of different populations of satellite cells, somewhat possible by the utilization of theoretical models. Therefore, the objective this study is characterize the role of theories and perspectives related to complexity and organization.

Key-words: complexity, organization, physical exercise 